\title{
Impact of Climate Change on Potato (Solanum tuberosum L.) Production and Adaptation strategies: A Review
}

\author{
Mulugeta Erkalo \\ Department of Horticulture and Plant Science, College of Agriculture and Veterinary Medicine, Jimma \\ University, P.O. BOX 307, Jimma, Ethiopia
}

\begin{abstract}
Potato (Solanum tuberosum L.) is considered as the high potential food security crop and a major instrument for poverty alleviation in Ethiopia. However, it is most vulnerable to climate change due to its exact climatic requirement for various physiological processes. There are many indicators of environmental stresses including climate change, especially global warming, are severely affecting potato growth and productivity worldwide. The changing climate will affect the potato production adversely due to drought ,salinity,frost,flooding, erratic unseasonal rains ,surface temperature, increase in $\mathrm{CO}_{2}$ fertilization, but decreases after some extent. Besides, anthropogenic activities such as $\mathrm{CO}_{2}$ may increase crop yields due to increased $\mathrm{CO}_{2}, \mathrm{CH}_{4}$ and $\mathrm{CFC}$ 's are contributing to the global warming. Under changing climatic situations crop failures, longer growing season, shortage of yields, reduction in quality, influence the pest and disease occurrences, host-pathogen interactions, distribution, and ecology of insects, there by becoming major setback to potato cultivation. Therefore, adaptation strategies needed such as cropping systems and other inputs, shifting growing areas and planting date, improving water management and breeding new tolerant potato varieties. This paper reviews verified that recent impact of climate change in potato production and adaptation strategies.
\end{abstract}

Keywords: Adaptation strategies, Climate change, Drought, Global warming

DOI: $10.7176 / \mathrm{JBAH} / 9-9-07$

Publication date:May $31^{\text {st }} 2019$

\section{INTRODUCTION}

Potato (Solanum tuberosum L.) is the most important root and tuber crop worldwide and multifaceted as a staple crop that addresses nutritional security especially for a large number of food-insecure smallholder farmers and pastoralists in the country (Thiele et al., 2010; He et al., 2012 ; Dandena , 2018). In addition, potato production recommended for highland areas is expanding to the lowland parts of the country due to its potential for production in a short period and a horticultural crop for its high value per unit area of land (Demo et al., 2015; Guchi, 2015; Sanginga and Mbabu, 2015). It ranked fourth in the world among food crop in terms of the volume of production following maize, wheat, and rice (FAOSTAT, 2017) and potato is grown in more than 130 countries where three-fourths of the world's population lives and consumed almost daily by more than a billion people (Zebarth et al., 2012). The total world potato production is estimated at 381,682,000 tonnes in 2014 (FAOSTAT, 2017). Potato cultivation is expanding strongly in the developing world including Africa, where the potato's ease of cultivation and nutritive content has made it a valuable food security and cash crop for millions of farmers (Mackay and Lutaladio, 2010). But, changes in the Earth's climate are threatening to negatively impact the growth and production of potato in the world (Londhe, 2016) and Ethiopia is often cited as one of the most extreme examples (Conway et al., 2011 ; Yohannes, 2016).

Currently, potato is considered as the high potential food security crop and a major instrument for poverty alleviation in Ethiopia, due to its high yield potential and nutritional quality tuber, short growing period and plasticity to environmental conditions. Besides, potato production serves as mean to overcome food shortage periods 'hungry months', since it matures before the harvest as compared with other cereals (Ayalew, 2014 ; Gebru et al.,2017). In terms of area cultivated and production accounted for $81.74 \%$ and $83.66 \%$ of the total root crop respectively (CSA, 2016). Potato is potentially grows in different corners of the country, However, there is a lot of heterogeneity in potato productivity depending upon mostly on management and climatic conditions (Ayalew, 2014). Also, its yield and quality are both dependent on variety and cultural practice as well as environmental condition, including rainfall, temperature, light, and CO2 (Naitam et al., 2016). Not only the potato cultivation is facing several challenges to maintain and improve production like highly sensitive to the projected climate change. As well as affecting potatoes directly, climate change will also affect the distributions and populations of many potato diseases and pests (Singh et al., 2013 ; Demo et al., 2015). Potato is a temperate crop and more erratic rainfall patterns and unpredictable high temperature spells consequently reduce crop productivity and its quality (Bhardwaj, 2012; Singh et al., 2013 ; Jatav et al., 2016).

Climate change is a key issue, which has the potential to change the production and environmental order landscape (Blom-Zandstra ; Verhagen, 2015). Even though climate change per se is not necessarily harmful; the problems arise from extreme events that are difficult to predict. It may be a change in the mean of the various climatic parameters such as temperature, precipitation, relative humidity and atmospheric gases composition etc. 
and in properties over a longer period of time and a larger geographical area (Ayyogari et al., 2014). Increase in $\mathrm{CO}_{2}$ may increase crop yields due to increased $\mathrm{CO}_{2}$ fertilization, but decreases after some extent (Laux et al.,2010; Singh et al., 2013 ;Yohanne, 2015). In addition, the yield increases by about 10 percent for every extra $100 \mathrm{ppm}$ (Jatav et al., 2016). Agricultural activities are affected by climate change affects due to their direct dependence on climatic factors. Anthropogenic activities such as $\mathrm{CO} 2, \mathrm{CH}_{4}$, and $\mathrm{CFC}$ 's are contributing to the global warming and dioxides of nitrogen and sulphur are causing depletion of ozone layer and permitting the entry of harmful UV rays (Debela et al., 2015). These effects of climate change also influence the pest and disease occurrences, host-pathogen interactions, distribution and ecology of insects, time of appearance, migration to new places and their overwintering capacity (Ayyogari et al.. 2014). Climate change, also called global warming $(\mathrm{GW})$, refers to the rise in average surface temperatures on Earth. Global warm is related to the increase of atmospheric $\mathrm{CO}_{2}$ concentration which is likely to increase crop yields, particularly when water limits crop production (Naitam et al., 2016). It is predicted to have significant effects on global potato production (Ayyogari et al., 2014). As for the effects of increasing levels of ozone, experiments indicate an overall reduction of photosynthetic efficiency and a significant decrease in tuber starch content, but an increase in the ascorbic acid concentration (Ramteke et al., 2016).

The impact of global warming on regional precipitation is difficult to predict owing to strong dependencies on changes in atmospheric circulation (Debela et al., 2015), especially global warming, are severely affecting plant growth and productivity worldwide (Gill and Tuteja, 2010). Although there is increasing confidence in projections of a general increase in high-latitude precipitation, especially in winter, and an overall decrease in many parts of the tropics and sub-tropics (IPCC, 2014). However, large levels of uncertainty exist with temporal and spatial variability of rainfall (Adhikari et al., 2015).

Higher temperatures also increase the crop water requirement, which together with changing rainfall patterns could bring about greater drought stress risks for potato. Crop growth models suggest potato yield decreases in consequence to climate change of up to $32 \%$ on a global scale until 2050 ( Schafleitner et al.,2011). According to Sorecha (2017) reviewed that in Ethiopia the challenge of climate change is very serious, given the degraded lands combined with highly variable rainfall and high temperature increment. The current climate change and variability is characterized by shorter rainfall season, erratic distribution (in time and space) with a decreasing amount from year to year. During the last four decades, a number of severe droughts exert extensive loss of human and property in the country, often covering the greater Horn of Africa. The observed changes are likely flawed by network density changes and measurement errors in the first half of the 20th century (Fig 1). For this reason potato production must be adapted to climate change to avoid reductions in crop yields. Therefore, the aim of this paper is to review the findings impact of climate change on potato production, indicate the adaptation strategies for growers, andpropose future research directions.
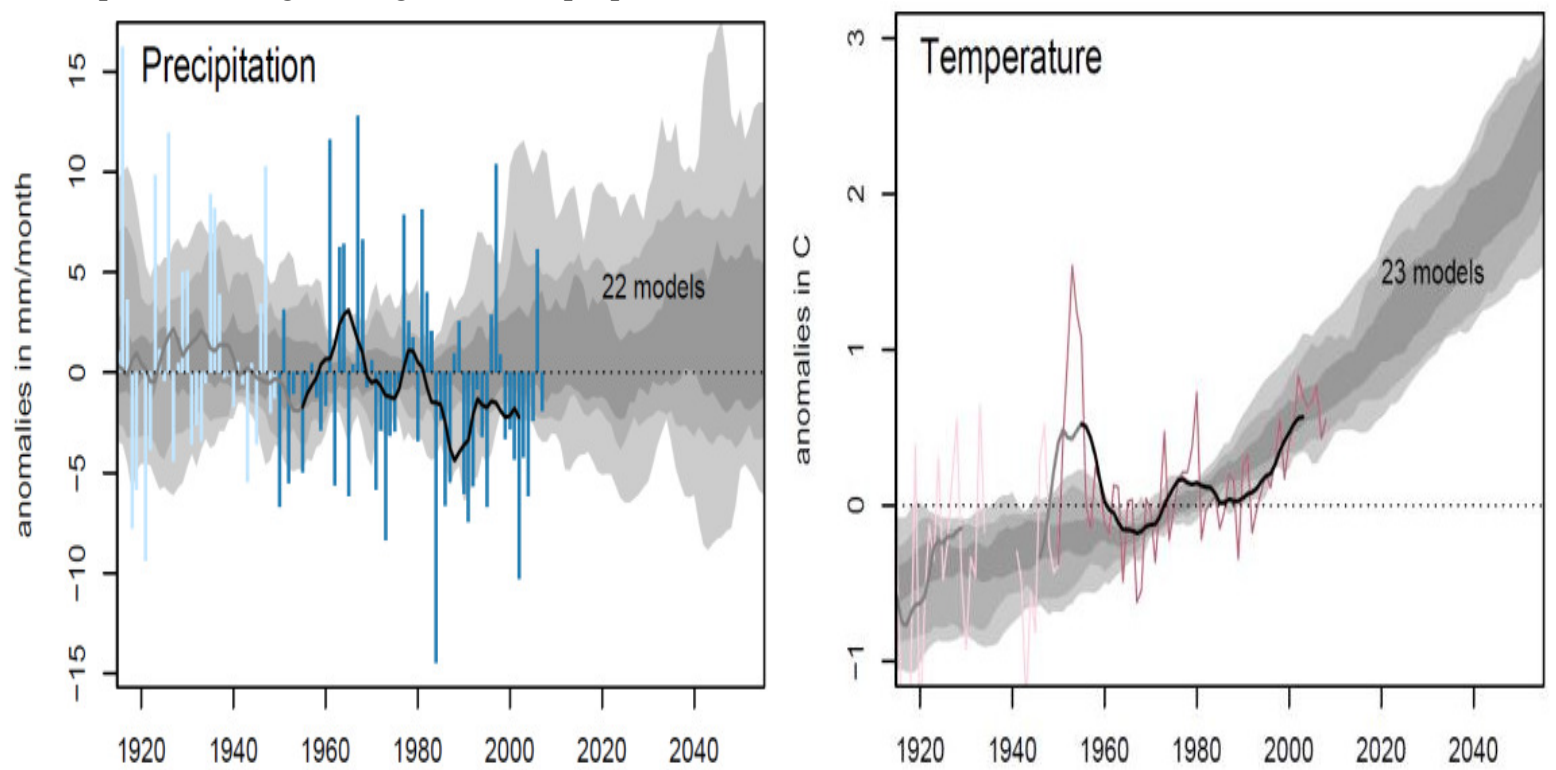

Figure 1 Observed precipitation and temperature changes in Ethiopia along with simulated changes by 22/23 global climate models (adapted from IPCC, 2007).

\section{LITERATURE REVIEW}

\subsection{Impacts of Climate Change on Potato Production}

2.1.1. Effect of carbon dioxide

Due to increased anthropogenic activities, concentration of greenhouse gases like $\mathrm{CO} 2$ and $\mathrm{CH} 4$ is increasing in 
the atmosphere day-by-day (McMichael, 2013 ; Blom-Zandstra and Verhagen, 2015). However, potato production and yields are predicted to benefit from increased carbon dioxide concentrations in the atmosphere (CWSI, 2012) in their photosynthetic rates which can increase their growth rates and because potatoes partition more starch to the edible tubers under elevated carbon dioxide levels. The effect of elevated $\mathrm{CO}_{2}$ concentration suggests positive effect on growth and yield with only few negative influences (Singh et al., 2013). On the other hand, higher levels of atmospheric carbon dioxide also results in potatoes having to open their stomata less to take up an equal amount of carbon dioxide for photosynthesis, which means less water loss through transpiration from stomata. As a result, the water use efficiency of potato plants is predicted to increase (Ayyogari et al., 2014).

Elevated $\mathrm{CO}_{2}$ may increase $\mathrm{C}_{3}$ plant canopy size and density, resulting in a greater biomass with a much higher microclimate relative humidity and the slower decomposition rate due to increased bio mass as a result of elevated $\mathrm{CO}_{2}$ will likely to increase the pathogen survival and helps in overwintering when these conditions are accomplished by warmer temperatures in winter. This is liable to promote plant diseases such as rusts, powdery mildews, leaf spots and blights (Das et al., 2011; Singh et al., 2013; Londhe, 2016 ; Schoville et al., 2017).

\subsubsection{Effect of temperature.}

Potato tuber growth and yield can be severely reduced by temperature fluctuations outside $5-30^{\circ} \mathrm{c}$ (Singh et al., 2013). For instance:-temperatures above $30^{\circ} \mathrm{C}$ can have a range of negative effects on potato( i.e. the crop will not tuberize and will grow only vegetatively) or slowing tuber growth and initiation , less partitioning of starch to the tubers, physiological damage to tubers (e.g. brown spots), shortened/non-existent tuber dormancy, making tubers sprout too early (Dandena,2018). In the other scenario, the effects of climate change on crop production can be complex that depending on the temperature regime and the crop high temperatures can lead to low yields due to increased development rates, higher respiration, and long growing season (Yohanne, 2015 ; Naitam et al., 2016). Conversely, a short growth cycle can also be beneficial, e.g., to escape drought or frost, and the use of late-maturing cultivars could offset the effect of high development rates. Some amount in environments where low temperatures now limit production, global warming could lead to a beneficial lengthening of the growing season and temperatures close to optimal for assimilation (Naitam et al., 2016). Moreover, fluctuations in daily mean maximum and minimum temperature is the primary effect of climate change that adversely affects potato production as many plant physiological, biochemical, and metabolic activities. Whereas, potato is well known for its exact temperature and day length requirement for tuber formation as well as flowering, so it becomes the most vulnerable crop for climate change (Ayyogari et al.. 2014). Lizana et al. (2017) reported that increased temperature within the favorable range at tuber bulking does not reduce potato yield. However, the first half of the tubers filling is sensitive to temperature increases. Over the last decades, the temperature in Ethiopia increased at about $0.2^{\circ} \mathrm{C}$ per decade (Gebreegziabher et al..2014). The Intergovernmental Panel on Climate Change predicts global temperatures to increase between 1.1 and $6.4{ }^{\circ} \mathrm{C}$ by 2100 (IPCC, 2014). The effect of increased temperatures on potato production in specific areas will vary depending partly on the current temperature of that area. Temperature effects are increased water deficits and excess soil water demonstrating that understanding the interaction of temperature and water will be needed to develop more effective adaptation strategies to offset the impacts of greater temperature extreme events associated with a changing climate (Hatfield and Prueger 2015).

Singh et al.(2010), who reported increase in temperature favors the potato cultivation by prolonging the crop growing season in high altitudes and temperate regions of the world like Europe, Russia and in India, Himalayan, and other mountain regions and frost prone states like Haryana and Punjab (Table 1) whereas, it disfavors the potato production by shortening the growing period in subtropical plains such as West Bengal and Bihar during winter season. In addition, temperature can affect the rates of growth, development, and mortality of pests of potato (Singh, et al., 2013; Hatfield and Prueger, 2015).

Table 1 Predicted impact of climate change without adaptations in India under optimal management (adapted from Singh et al., 2010)

\begin{tabular}{lcc}
\hline State & Change (\%) from current productivity \\
& By 2020 & By 2050 \\
\hline Uttar Pradesh & -1.61 & 9.08 \\
West Bengal & -4.86 & -16.11 \\
Bihar & -3.01 & -11.5 \\
Punjab \& Haryana & 7.31 & 3.66 \\
Madhya Pradesh & -6.64 & -20.63 \\
Gujarat & -16.75 & -55.1 \\
Maharashtra & -8.82 & -35.29 \\
Karnataka & -18.68 & -45.73 \\
\hline
\end{tabular}

Recently, National Meteorology Agency of Ethiopia reported that the average minimum and maximum temperatures have been increased by $0.25^{\circ} \mathrm{C}$ and $0.1^{\circ} \mathrm{C}$ per year, respectively over the past decades; also, rainfall 
has been characterized by its high variability over the past 50 years (Sorecha, 2017). Moreover, higher temperatures result in greater evaporation, meaning soil moisture is reduced, reinforcing drier conditions, and intensifying the impacts of failed rains (Carty, 2017). The higher temperatures in growing areas at higher latitudes will lead to a longer growing season and this will in turn lead to increased pest and disease pressure, due to result in less cold stress and longer growing seasons for warm climate pests and more heat stress for temperate species. Elevated temperatures also can suppress defense responses in plant hosts resulting in increased severity of disease. Besides, the effect of elevated temperature on late blight at global level revealed that with rise in global temperature of $2^{\circ} \mathrm{C}$, there will be lower risk of late blight in warmer areas $\left(<22^{\circ} \mathrm{C}\right)$ and higher risk in cooler areas $\left(>13^{\circ} \mathrm{C}\right)$ with early onset of the epidemics. It may result in population increases due to shorter life cycles and faster generation times (Rogers, 2013 ; Singh et al., 2013).

Potato tubers with high starch content are favored by the processing industry. At low temperatures, starch is converted into the sugar, which causes browning due to charring of sugar while chips making there by reduces their preference by the processing industry. This ultimately results in increased post-harvest losses more than the present level, which is figured as $40-50 \%$. This is most common problem in areas where night temperatures fell below optimum during winter season (Singh, 2010). However, increased temperature causes migration of insect species towards higher latitudes, while in the tropics higher temperatures might adversely affect specific pest species. High atmospheric temperature increases insect developmental and oviposition rates, insect outbreaks and invasive species introductions, whereas it decreases the effectiveness of insect bio-control by fungi, reliability of economic threshold levels, insect diversity in ecosystems and parasitism as reviewed by Das et al.(2011).
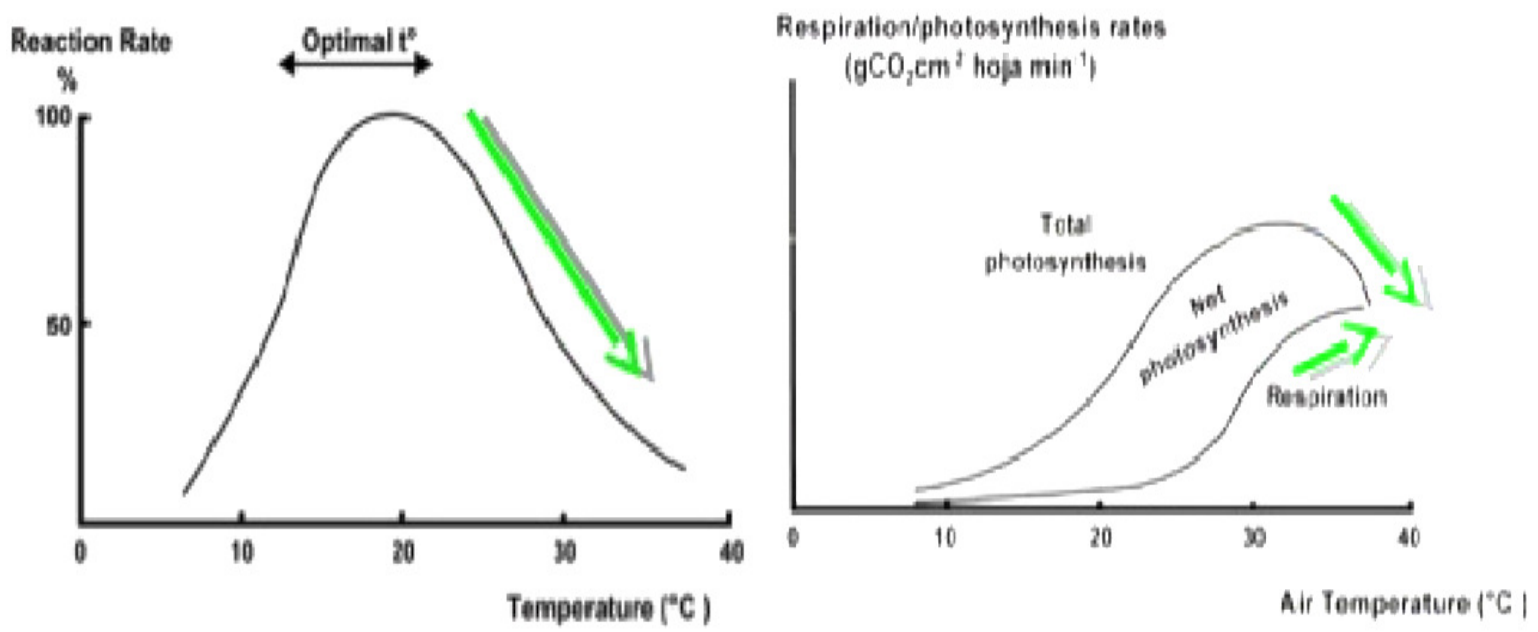

Figure 2. Effect of temperature on potato production (adapted from Quiroz et al.,2011)

\subsubsection{Drought and salinity}

With the current unpredictable annual rainfall and droughts once every five years with increasing temperatures, climate change presents challenges to feed Ethiopia (Dandena, 2018). Drought and salinity are the most important side effects of global warming and abiotic stresses that affect the normal growth and development of plants. Potato is regarded as a moderately salt-sensitive and drought-sensitive crop (Zhang et al., 2011 and Si et al., 2012) due to that inability to water transport to leaves leads to photosynthesis declines, Leaf rolling and other morphological adaptations, stoma closure reduces evaporative transpiration induced by ABA. Consequently lower internal water potential and water attracting (Loredana et al., 2011). According to Blom-Zandstra and Verhagen (2015) verification reported that potato leaves are very sensitive to saline water and are severely damaged by overhead irrigation with saline water especially at the beginning of tuber formation. Climate change is expected to aggravate drought events throughout the world, resulting in large-scale ecosystem alteration and failure of drought-sensitive crops. In addition, periods of drought vary from year to year in both severity and length, making it difficult for plants to adapt to more severe conditions. Many modern varieties of potatoes are considered drought sensitive (Blom-Zandstra and Verhagen, 2015; Orgodol et al., 2015).

Potato is sensitive to high temperature and moisture deficits. For this reason, potato production is said to be vulnerable to the anticipated climate change. A critical period of water stress mostly affect final tuber yield in addition to salinity tends to reduce the tuber yield in potato (Muthoni and Kabira, 2016). Potatoes are sensitive to soil water stress (either drought or water logging), compared to other crops such as wheat and drought tolerance has received more attention in cereals than potato and need frequent irrigation, especially while tubers are growing (FAO, 2012 ; Monneveux et al. ., 2013).

As indicated by Pehrson et al.(2010) and McMichael, (2011) rainfall patterns will also change, with 
rainfall increasing in some regions and seasons and decreasing in others, thus in nature potato crop is sensitive to water shortage as cited by due to their shallow rooting system characteristic and grown on soil type having low water holding capacity, since this kind of soil is preferable for the ease of potato tuber harvesting (Wishart et al., 2013). This makes potato crop more susceptible to water stress than a lot of other crop species. Reduced rainfall in many areas is predicted to increase the need for irrigation of potato crops. For example, in the UK the amount of arable land suitable for rainfed potato production is expected to decrease by at least 75\% (Daccache et al., 2012).Although, most potato producing farmers in Ethiopia are dependent on rain water, some farmers produce potato by using irrigation as a water source based on accessibility of irrigation water as well as irrigable lands. In addition, the farmers who practice irrigation are able to produce three times per year. Hence, to meet the water requirement and reach with high quality and quantity of final potato tuber yield, efficient and effective water management is crucial (Yibrah and Araya, 2015).

\subsubsection{Pests and disease}

Climate change may have a secondary effect on the increase of the amount of pests and diseases with a concomitant effect on crop growth performances and in return plant defense mechanisms in which stress hormones ABA(Blom-Zandstra and Verhagen, 2015). Due to effects of climate change also influence the pest and disease occurrences, host-pathogen interactions, distribution and ecology of insects, time of appearance, migration to new places and their overwintering capacity (Ayyogari et al.,2014). As well as affecting potatoes directly, climate change is forecast to affect many potato pests and diseases. Potato pests and diseases are $75 \%$ of potato production today would be lost to pests. Global warming will have a serious impact on viral diseases through the altered biology of insect vectors (Singh et al., 2013). High atmospheric $\mathrm{CO}_{2}$ increases food consumption by caterpillars, reproduction of aphids and decreases the nitrogen based plant defense, the beneficial effects are increased predation by predators, effect of foliar application of Bt., carbon based plant defense and decreased insect development rates as reviewed by Das et al. (2011). Besides, Several pathogens causing potato blackleg disease (e.g. Dickeya) can grow and reproduce faster at higher temperatures and so will likely become more of a problem.(Czajkowski,2012 ;Schoville et al., 2017). For example, Late blight benefits from higher temperatures and wetter conditions (Forbes, 2012). On the other hand, Climate change can be reducing the efficacy of herbicides (glyphosate) \& management of invasive weeds.

In Ethiopia, Mostly weather affects the severity of many plant diseases, and climate change is likely to alter patterns of crop disease severity. Some indicator research illustrated that the countries selected to represent specific agro-ecosystems, for a susceptible cultivar late blight risk increased in Rwanda and Ethiopia; all other regions examined had a slight decrease in the blight unit accumulation at the country level (Table 2). However, the blight unit accumulations shift within the growing areas for each country, which could influence potato production as some areas experience increased late blight severity, and others experience decreased late blight severity (Sparks et al.,2014). Certainly, Warmer temperatures can also lead to increased lignification within the plant, which can protect against pathogen infections (Sorecha, 2017). Fewer frost events may also aid in reducing plant disease as frosts can cause injury points on plants, which act as potential entry sites for various pathogens (Liu et al., 2017). Therefore, evaluating such future patterns can help in prioritizing adaptation measures research efforts such as crop breeding and disease management.

Table 2 Mean change in blight units are a predictor of biological risk based on weather and potato genotypic resistance (adapted from Sparks et al. ,2014).

\begin{tabular}{cccccccc}
\hline & & \multicolumn{3}{c}{$\begin{array}{c}\text { Susceptible Genotype Blight } \\
\text { Units }\end{array}$} & \multicolumn{3}{c}{ Resistant Genotype Blight } \\
Agroecosystems & Country & 1975 & 2050 & Change & 1975 & 2050 & Change \\
\hline & Colombia \& & & & & & & \\
Andean Highlands & Ecuador & 2.23 & 2.2 & -0.03 & 1.03 & 1 & -0.03 \\
Ethiopian Highlands & Ethiopia & 0.63 & 0.68 & 0.05 & 0.33 & 0.35 & 0.02 \\
Lake Kivu Highlands & Rwanda & 2.41 & 3.55 & 1.14 & 1.43 & 2.22 & 0.79 \\
Himalayan Highland & Nepal & 1.47 & 1.45 & -0.02 & 0.81 & 0.85 & -0.02 \\
\hline
\end{tabular}

\subsection{Adaptation strategies of Potato Production to Climate Change}

Recently as mentioned, global potato production was assessed that without adaptation measures, it is predicted that potato yield will decrease by $18-32 \%$ with climate change and by $9 \%$ to $18 \%$ with adaptation in $2040-2069$. The most vulnerable area is the tropical belt, where the loss could be more than 50 percent (Luck et al., 2011). Climate change has serious implications for the potato industry both in terms of the need to adapt to a changing climate and to modify practices to mitigate for the impacts of climate change (Prokopy et al., 2015). Climate change adaptation is a continuous process requiring location-specific response. Although Gebreegziabher et al.. (2014) and Yohannes (2016) they currently emphasized the fact that climate change can have significant negative impacts on Ethiopia's agriculture unless appropriate adaptation measures are adopted. Adaptation strategies also have short and long-term changes to human activities that respond to the effects of changes in 
climate. These the most feasible and recommended measures to adapt potatoes to climate change could include in particular the choice and change of species and varieties, change planting dates, developing new drought and heat resistant varieties, use cropping systems (new farm management practices) and other inputs (i.e. fertilization, plant protection, irrigation, tillage methods, tuber storage, other field operations) improving crop residues and weed management, more use of water harvesting techniques, better pest and disease control for crops, implementing new or improving existing irrigating systems /reducing water leakage, soil moisture conservation mulching, manure management and agroforestry (Rickards and Howden ,2012 ; Singh et al.. ,2013).

\subsubsection{Cropping systems}

Cropping system development and other inputs (fertigation, tillage methods, tuber storage (DLH), other field operations), is versatile and easily practicable measure for farmers that can help potato adapt. For example the use of crop mixtures that have several crops growing at one time can help systems exhibit greater durability during periods of high water or heat stress (Mukherjee, 2017). Cropping system adaptations of potato cultivation include altering inputs such as varieties to those with more appropriate thermal time, and vernalization requirements and / or with increased resistance to heat shock, and drought, altering fertilizer rates to maintain grain or tuber quality consistent with the prevailing climate, altering amounts and timing of irrigation and other water management (Jatav et al., 2016).

Diversifying income through altering integration with other farming activities ( livestock rising), improving the effectiveness of pest, disease, and weed management practices. Also, wider use of integrated pest and pathogen management, development, and use of varieties and species resistant to pests and diseases, and maintaining or improving quarantine capabilities and monitoring programs and using climate forecasting to reduce potato tuber production risk (Yibrah and Araya, 2015).

\subsubsection{Shifting growing areas and planting date}

Change in growing areas and cropping calendar is common adaptation to climate change at the farm level, which largely involves altering the timing of farm activities to suit climatic variations. At the same time potato production is predicted to become possible in high altitude and latitude areas where it would previously have been limited by frost damage. These changes in crop yields are predicted to cause shifts in the areas in which potato crops can be viably produced. Also, differences in sowing date can directly influence utilization of agricultural climate resources, thereby affecting crop growth and yield (Hoffmann and Kluge-Severin 2010). Agro meteorological studies have dealt with what are feasible sowing dates for crops in order to effectively prevent the adverse impacts of climate change, fully utilize climate resource, and ensure better growth and high yield for crops (Ferrise et al.. 2010). In addition, according to Yohannes (2016) Eastern Ethiopia reigns such as Gojam (Choke mountain area) and Hararghe already changing planting dates of crops helps greatly for the farmers' agricultural practice.

A potential problem in shifting potato production is competition for land between potato crops and other crops and other land uses. The farmers have already implemented marginal adaptation measures by changing their planting date and crop varieties in East Africa, however, soil, water and land management practices have not been widely adopted (Kristjanson et al.. 2012 ). People living in Africa's arid and semi-arid lands face huge climate-related challenges, including less predictable rainfall, more frequent extreme weather events and increasing temperatures (Ketiem et al., 2015), due to these shifting growing area and altering planting date may be remarkable adaptation measures. Climatic conditions for agricultural production have been undergoing changes with global warming, causing changes not only in crop growth and development, yield and quality but also in phonological time (Laux et al. ,2010 ; Van Oort et al.,2012). For example, In Limpopo, predicted that the length of the growing season suitable for potato is largely determined by the heat-free period as stated by Franke et al. (2014).

\subsubsection{Improving water capture, use and irrigation}

Future climate change impacts on water resources in East Africa show that runoff will increase in the northern regions and decrease in the southern regions (Adhikari et al.,2015). In Ethiopia, Yohannes (2016) revealed that the major soil and water conservation (SWC) (i.e. Ditch and check dam constructions, terracing and different water harvesting) practice that helps to adapt climate change. This indicates the negative impact of climate change can be compensated by using of different types of irrigation. Thus, improving water management is very important to implement irrigation management strategies to minimize the effects of water stress under different climate conditions (Razzaghi et al., 2017). Potato is highly sensitive to water stress (dependent on cultivar rooting depth). Even a short period of water shortage can affect tuber production and quality. However, field potato crops undergoing mild water deficit conditions may acclimate to subsequent severe water deficits (Kumar, 2015; Yibrah and Araya, 2015).

Wider use of technologies to harvest water, conserve soil moisture (e.g., crop residue retention), and use and transport water more effectively where rainfall decreases (Jatav et al., 2016).For this cause, adaptation will require cost-effective investments in water infrastructure. Managing water to prevent water logging, erosion and 
nutrient leaching where rainfall increases. Altering the timing or location of cropping activities. Especially during the dry season for smallholders, shallow and hand- dug wells could supplement water limitations, rainwater harvesting and storage from ground surfaces and rooftops for use during the dry season is another option to cope with rainfall variability (Elliot et al. . 2011). Groundwater provides a reliable, high quality, and accessible source of freshwater that enables farmers to mitigate against the production risks associated with extreme weather events and climate variability. Groundwater-fed irrigation has supported growth in agricultural production around the world by allowing farmers to buffer production against the risks associated with variable and uncertain climatic conditions. Declining well yields, which control the potential rate and feasibility of groundwater abstraction, are likely to restrict adaptation to drought, but this interaction has largely been neglected in previous research (Foster et al., 2015). Groundwater sources will be less impacted by near term climate change providing an alternative source of water for all regions (Bonsor et al.. 2010) .

Overall, Potato requires frequent watering while tubers are growing to maintain yields. Due to decreasing water availability predicted in some areas, improving irrigation techniques and water capture is necessary to maintain potato crop yields without putting too much stress on water supplies. An example of an irrigation technique aimed at reducing water use that has been trialled on potatoes is Subsurface Drip Irrigation (SDI) (FAO, 2012).
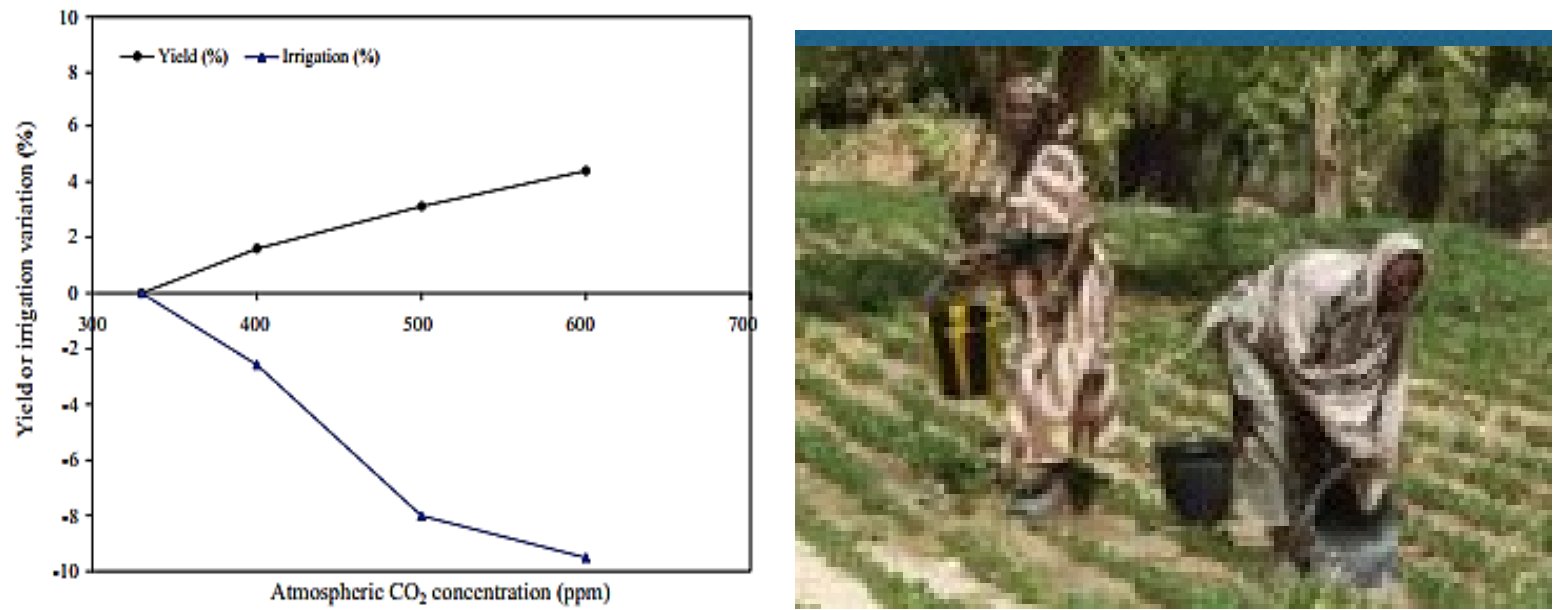

Figure 3 The potential fresh tuber yield and water use efficiency (WUE) showed a positive response to carbon assimilation enhancement due to increased levels of atmospheric $\mathrm{CO}_{2}$ (adapted from Daccache et al., 2011; Opere et al., 2012)

\subsubsection{Breeding new tolerant potato varieties}

Developing crop varieties, including potatoes tolerant to drought and heat, could be the priority research area in Ethiopia as a climate change adaptation strategy (Yibrah and Araya, 2015; Dandena, 2018). Hence, crop breeding for development of new climate tolerant crop varieties is a key tool for adapting agriculture to a changing climate. History and current breeding experience indicate that natural biodiversity within crops has allowed for plant adaptation to different conditions, providing clear evidence that plant breeding has great potential to aide in the adaptation of crops to climate change. Nevertheless, Past potato breeding mainly focused on high yield, yield stability, product uniformity, tuber quality, and resistance to pests and pathogens and was less oriented toward abiotic stress tolerance, as the latter has not been recognized as primary breeding aim (Schafleitner et al., 2011). In potato cultivation, plant breeding programmes are expected to adapt many crops to increased duration of growing seasons and, concurrently, to develop drought and temperature stress tolerance. especially in terms of managing the productivity and sustainability of food crops. On the other hands, breeding for abiotic stress is difficult for two reasons: the erratic nature of climate stress effects and the complexity of plant abiotic stress tolerance. Nature and strength of abiotic stress events are highly variable and their duration may change from year to year-selecting for stress tolerance under natural environments difficult, as different stress levels over seasons might activate different stress response mechanisms. Accordingly, in each selection cycle, different genes would be selected for, resulting in no breeding progress over time. The development and dissemination of drought tolerant crop cultivars could also help minimize the climate change impact in drought prone areas (Bonsor et al., 2010).

Two main approaches are taken to create new potato varieties: 'traditional' plant breeding techniques and genetic modification. These techniques may play an important role in creating new cultivars able to maintain yields under stressors induced by climate change. Traits that may be helpful in reducing negative impacts of climate on potato production include: Heat stress tolerance, in particular the ability to maintain tuber growth and initiation under high temperatures. Developing cultivars with greater heat stress tolerance is critical for 
maintaining yields in countries with potato production areas near current cultivars' maximum temperature limits. 1) Drought tolerance: This includes better water use efficiency (amount of food produced per amount of water used) as well as potatoes that can be exposed to short drought periods and recover and produce acceptable yields. 2) Deeper root systems: could also be beneficial, as most commercial potato cultivars need frequent irrigation due to their shallow roots (FAO, 2012). 3) Fast growth / early maturation: Potatoes that grow faster could help adjust to shorter growing seasons in some areas due to that the late variety may have benefited more because of a relatively earlier tuber formation (Blom-Zandstra and Verhagen, 2015). Again, also reduce the number of life cycles pests such as potato tuber moth can complete in a single growing season. Disease resistance:- Potatoes with resistances to local pests and diseases could be helpful, especially in adapting to diseases spreading into new areas. A major source of genetic material for creating new potato cultivars is the many species closely related to potato many of which can be crossbred with potato.

\section{SUMMARY AND CONCULSION}

Potato is the top of most important food crop in terms of human consumption over the worldwide. In Ethiopia, its production serves as mean to overcome food shortage periods 'hungry months 'crop, since it matures before the harvest of other staple food crops such as cereals. It is potentially grows in different corners of the country. Whereas, there is a lot of variability in potato yields depending upon mostly on agronomic practices and climatic conditions. Additionally, due to its sensitivity to high temperature and moisture deficits, the production of the crop is very low as compared with the world average production. One of the factors for the low yield is the impact of climate change. So that the objective of this review paper is to review the impact of climate change on potato production and adaptation strategies.

Agronomic activities are affected by climate change disruption due to their direct reliance on climatic factors. In high latitude areas with low temperature, increased temperature due to climate change could allow for longer growing season. Climate change is a real continuous process and happening now. Climate change may be a change in the mean of the various climatic parameters such as temperature, precipitation, relative humidity, and atmospheric gases composition etc. and in properties over a longer period and a larger geographical area. Crop production affects climate through emissions of greenhouse gases (GHGs) such as carbon dioxide, methane and nitrous oxide. These emissions come directly from use of fossil fuels, tillage practices, fertilized agricultural soils and livestock manure in large proportion. Among atmospheric gases $\mathrm{CO}_{2}$ is playing major role effecting growth and development as well as pest and diseases of potato crops and Experiments on potato have shown that increasing $\mathrm{CO}_{2}$ concentrations have little effect on production of biomass above ground, but below ground biomass is significantly enhanced, through higher numbers of tubers and bigger tuber size. However, effects of temperature generated by global warming on crop plants are the major among all the climate change effects. It is again responsible for other stresses like drought or moisture stress, salinity and floods and water logging in coastal areas due to melting of polar ice and increased sea levels. More erratic rainfall patterns and unpredictable high temperature spells consequently reduce crop productivity. Potato production system is depending on rainfed culture likely to suffer losses due to heat, erratic weather, and deceased irrigation availability. Water policy will need to consider the implications for water demand of agricultural change due to climate change. In addition to potato production could be a solution for climate change by the widespread adoption of mitigation and adaptation actions. Adaptation strategies can help minimize negative impacts likes cropping systems and other inputs viz. fertilizer, tillage methods, grain drying, other field operations, shifting growing areas and planting date, improving water management and breeding new tolerant potato varieties.

\section{Future Line of Work}

Further study therefore require quantification of regional vulnerability and impact assessment, development of early warning disease-forecasting systems, breeding short duration and heat-tolerant cultivars, breeding drought, salinity-tolerant, and disease resistant cultivars, advance planning for possible relocation and identification of new areas for potato cultivation, improved agronomic management for water and fertilizer use efficiency, development of agro-techniques for warm weather cultivation and potato-based cropping systems, development of virus and late blight resistant varieties, rescheduling of chemical sprays based on new emerging pathogen population and development of integrated pest management strategies. It is also advisable to include appropriate planting date combined with the onset, cessation of the rains and the seasonal dry spells, use of resilient varieties to climate change and optimum fertility level should be studied.

\section{ACKNOWLEDGMENTS}

The authors wish to acknowledge Jimma University College of Agriculture and Veterinary Medicine for Review facilities. 


\section{REFERENCES}

Adhikari, U., A. P. Nejadhashemi, and M. R. Herman, 2015 . A review of climate change impacts on water resources in East Africa. Trans. ASABE In Review.

Ayyogari, K., Sidhya, P. and Pandit, M.K., 2014. Impact of climate change on vegetable cultivation-a review. International Journal of Agriculture, Environment and Biotechnology, 7(1), p.145.

Bhardwaj, M.L., 2012. Effect of Climate Change on Vegetable Production in India. vegetable production under Changing climate scenario, Dept. of Vegetable Science, Dr. YS Parmer University of Horticulture and Forestry, Solan, India, pp.1-12.

Blom-Zandstra, M. and Verhagen, A., 2015. Potato production systems in different agro ecological regions and their relation with climate change (No. 614). Wageningen UR.

Bonsor, H. C. , A. M. MacDonald , and R. C. Calow , 2010. Potential impact of climate change on improved and unimproved water supplies in Africa . RSC Issues Environ. Sci. Technol. $31: 25$ - 50 .

Carty, T., 2017. A Climate in Crisis: How climate change is making drought and humanitarian disaster worse in East Africa.

CIP, 2012.Genebank and Potato.International Potato Center( CIP). Retrieved 7 Nov. 2012.

Conway, D. and Schipper, E.L.F., 2011. Adaptation to climate change in Africa: Challenges and opportunities identified from Ethiopia. Global Environmental Change, 21(1), pp.227-237

CWSI,(2012).Climate change and potatoes: The risks, impacts and opportunities for UK potato production. Cranfield Water Science Institute(CWSI). Retrieved 7 November 2012.

Czajkowski, Robert,(2012). Why is Dickeya spp. (syn. Erwinia chrysanthemi) taking over? The ecology of a blackleg pathogen. Gewasbescherming, 39.pp.238-238.

Daccache, A.; C. Keay; R.J.A. Jones; E.K. Weatherhead; M.A. Stalham; J.W. Knox (2012). "Climate change and land suitability for potato production in England and Wales: impacts and adaptation". Journal of Agricultural Science. 150: 161-177.

Dandena Gelmesa (2018). Promoting Drought and Heat Resilient Potato Genotypes in Eastern Ethiopia, Drylands Coordination Group Report No. 77, Addis Ababa, Ethiopia, 1503-0601

Das, D.K. J. Singh, and S. Vennila. (2011). Emerging Crop Pest Scenario under the Impact of Climate Change A Brief Review. Journal of Agricultural Physics 11:13-20.

Debela, N., Mohammed, C., Bridle, K., Corkrey, R. and McNeil, D., 2015. Perception of climate change and its impact by smallholders in pastoral/agropastoral systems of Borana, South Ethiopia. Springer Plus, 4(1), 236.

Demo, P., Lemaga, B., Kakuhenzire, R., Schulz, S., Borus, D., Barker, I., Woldegiorgis, G., Parker, M.L. and Schulte-Geldermann, E., 2015. 11 Strategies to Improve Seed Potato Quality and Supply in Sub-Saharan Africa: Experience from Interventions in Five Countries. Potato and Sweet potato in Africa: Transforming the Value Chains for Food and Nutrition Security, 155.

Elliot ,M., A. Armstrong, J. Lobuglio , and J. Bartram, 2011. Technologies for climate change adaptation: the water sector . Roskilde: UNEP Risoe Centre, Roskilde, Denmark .

FAOSTAT. ( Food and Agriculture Organization Statics) , 2017. Production year book. Food and Agriculture Organization of the United Nation, Rome, http://faostat.fao.org.

FAO, 2012.Crop Water Information: Potato". FAO Water Development and Management Unit. Retrieved 7 November 2012.

Ferrise R, Triossi A, Stratonovitch P, Bindi M, Martre P. 2010. Sowing date and nitrogen fertilization effects on dry matter and nitrogen dynamics for durum wheat: An experimental and simulation study. Field Crops Research, 117, 245-257

Forbes, G. A.(2012). Implications for a warmer, wetter world on the late blight pathogen: How CIP efforts can reduce risk for low-input potato farmers. Retrieved 7 Nov. 2012.

Foster, T., Brozović, N. and Butler, A.P., 2015. Why well yield matters for managing agricultural drought risk. Weather and Climate Extremes, 10, pp.11-19.

Franke A.C., Steyn J.M and Haverkort A.J., (2014). Series: Potato production in achanging climate I. How will Limpopo cope? P. 38-41

Gill, S.S. and Tuteja, N., 2010. Polyamines and abiotic stress tolerance in plants. Plant signaling and behavior, $5(1)$, pp.26-33.

Gebreegziabher, Z., Mekonnen, A., Deribie, R., Abera S. and Kassahun M., 2014. Climate change can have significant negative impacts on Ethiopia's agriculture. EFD Discussion Paper 13-14

Gebru, H., Mohammed, A., Dechassa, N. and Belew, D., 2017. Assessment of production practices of smallholder potato (Solanum tuberosum L.) farmers in Wolaita zone, southern Ethiopia. Agriculture and Food Security, 6(1), p.31.

Gornall, J., Betts, R., Burke, E., Clark, R., Camp, J., Willett, K. and Wiltshire, A., 2010. Implications of climate change for agricultural productivity in the early twenty-first century. Philosophical Transactions of the Royal Society of London B: Biological Sciences, 365(1554), pp.2973-2989. 
Guchi, E., 2015. Disease management practice on potato (Solanum tuberosum L.) in Ethiopia. World Journal of Agricultural Research, 3(1), pp.34-42.

Hatfield, J.L. and Prueger, J.H., 2015. Temperature extremes: effect on plant growth and development. Weather and Climate Extremes, 10, pp.4-10.

He, Z., Larkin, R. and Honeycutt, W. eds., 2012. Sustainable potato production: global case studies. Springer Science \& Business Media.

Hoffmann C M, Kluge-Severin S. 2010. Light absorption and radiation use efficiency of autumn and spring sown sugar beets. Field Crops Research, 119, 238-244.

Intergovernmental Panel on Climate Change(IPCC), 2014. Climate Change 2014-Impacts, Adaptation and Vulnerability: Regional Aspects. Cambridge University Press.

Jatav, M.K., Dua, V.K., Govindakrishnan, P.M. and Sharma, R.P., 2016. Impact of Climate Change on Potato Production in India. Sustainable Potato Production and the Impact of Climate Change, p.87.

Kato, E. , C. Ringler, M. Yesuf, and E. Bryan . 2011. Soil and water conservation technologies: a buffer against production risk in the face of climate change? Insights from the Nile basin in Ethiopia . Agri. Econ. $42: 593-604$.

Ketiem, P., Diarra, A., Soura, A. and Konou, R., 2015. Strategies for adapting to water stress in the arid and semi-arid regions of Africa.

Kristjanson, P., Neufeldt, H., Gassner, A., Mango, J., Kyazze, F.B., Desta, S., Sayula, G., Thiede, B., Förch, W., Thornton, P.K. and Coe, R., 2012. Are food insecure smallholder households making changes in their farming practices? Evidence from East Africa. Food Security, 4(3), pp.381-397.

Laux, P., Jäckel, G., Tingem, R.M. and Kunstmann, H., 2010. Impact of climate change on agricultural productivity under rainfed conditions in Cameroon-A method to improve attainable crop yields by planting date adaptations. Agricultural and Forest Meteorology, 150(9), pp.1258-1271.

Liu, Y., Langemeier, M.R., Small, I.M., Joseph, L. and Fry, W.E., 2017. Risk management strategies using precision agriculture technology to manage potato late blight. Agronomy Journal, 109(2), pp.562-575.

Lizana, X.C., Avila, A., Tolaba, A. and Martinez, J.P., 2017. Field responses of potato to increased temperature during tuber bulking: Projection for climate change scenarios, at high-yield environments of Southern Chile. Agricultural and Forest Meteorology, 239, pp.192-201.

Londhe, S.L., 2016. Climate change and agriculture: Impacts, adoption, and mitigation. Handbook of research on climate change impact on health and environmental sustainability, pp.393-415.

Luck, J., Spackman, M., Freeman, A., Griffiths, W., Finlay, K. and Chakraborty, S., 2011. Climate change and diseases of food crops. Plant Pathology, 60(1), pp.113-121.

Mackay, G. and Lutaladio, D., 2010. Sustainable Potato Production. Guidelines for Developing Countries. Experimental Agriculture, 46(4), p.566.

McMichael, A.J., 2013. Globalization, climate change, and human health. New England Journal of Medicine, 368(14), pp.1335-1343.

Mimura, N., 2013. Sea-level rise caused by climate change and its implications for society. Proceedings of the Japan Academy, Series B, 89(7), pp.281-301.

Monneveux, P., Ramírez, D.A. and Pino, M.T., 2013. Drought tolerance in potato (S. tuberosum L.): Can we learn from drought tolerance research in cereals?. Plant Science, 205, pp.76-86.

Mukherjee, D., 2017. Improved Agronomic Practices and Input Use Efficiency for Potato Production under Changing Climate: Improved Practices for Potato Production. In Sustainable Potato Production and the Impact of Climate Change (pp. 105-132).

Muthoni, J. and Kabira, J.N., 2016. Potato Production under Drought Conditions: Identification of Adaptive Traits. International Journal of Horticulture, 6.

Naitam, R.K., Deshmukt, P., Ramteke, I.K., Singh, R.S. and Moharana, P.C., 2016. Climate Change and Land Suitability for Potato Cultivation in India. Sustainable Potato Production and the Impact of Climate Change, p.1

Opere, A., Oludhe, C. and Omondi, P., 2012. Resource guide on climate change science.

Orgodol,K.,Nyamgerel, K. and Oyun Erdene,S.,2015.Reflection of potato varieties to midseason water limitation. Mongolian journal of agricultural sciences, 13(2), pp.60-62.

Pehrson L, Mahler RL, Bechinski EJ, Williams C (2010) Water management practices used in potato production in Idaho. Am Potato J .87:253-260.

Prokopy, L. S., Arbuckle, J. G., Barnes, A. P., Haden, V. R., Hogan, A., Niles, M. T., \& Tyndall, J. (2015). Farmers and climate change: a cross-national comparison of beliefs and risk perceptions in high-income countries. Environmental management, 56(2), 492-504.

Quiroz, R., Yarlequé, C., Posadas, A., Mares, V. and Immerzeel, W.W., 2011. Improving daily rainfall estimation from NDVI using a wavelet transform. Environmental Modeling \& Software, 26(2), pp.201-209.

Razzaghi, F., Zhou, Z., Andersen, M.N. and Plauborg, F., 2017. Simulation of potato yield in temperate 
condition by the AquaCrop model. Agricultural Water Management, 191, pp.113-123.

Rickards, L. , and S. M. Howden . 2012 . Transformational adaptation: agriculture and climate change . Crop Pasture Sci. $63: 240-250$

Rogers, G., 2013. Understanding and managing impacts of climate change and variability on vegetable industry productivity and profits.

Sanginga, N. and Mbabu, A., 2015, Root and tuber crops (Cassava, yam, potato and sweet potato). In Proceedings of the An Action Plan for African Agricultural Transformation Conference, Dakar, Senegal (pp. 21-23).

Schafleitner, R., Ramirez, J., Jarvis, A., Evers, D., Gutierrez, R. and Scurrah, M., 2011. Adaptation of the potato crop to changing climates. Crop adaptation to climate change, pp.287-297.

Schoville, S.D., Chen, Y.H., Andersson, M.N.N., Benoit, J.B., Bhandari, A., Bowsher, J.H., Brevik, K., Cappelle, K., Chen, M.J.M., Childers, A.K. and Childers, C., 2017. A model species for agricultural pest genomics: the genome of the Colorado potato beetle, Leptinotarsa decemlineata (Coleoptera: Chrysomelidae). bioRxiv, p.192641

Si, H., Zhang, N. and Wang, D., 2012. Drought and Salinity Tolerance in Transgenic Potato. In Sustainable Potato Production: Global Case Studies (pp. 373-387). Springer Netherlands.

Singh, B.P., Dua, V.K., Govindakrishnan, P.M. and Sharma, S., 2013. Impact of climate change on potato. In Climate-Resilient Horticulture: Adaptation and Mitigation Strategies (pp. 125-135). Springer India.

Singh, J.P., S.S. Lal, and S.K. Pandy. 2010. Effect of climate change on potato production in India. Central Potato Research Institute .Shimla Newsletter 40:17-18

Sorecha EM (2017) Trend Analysis and Challenges of Adaptations to Climate Change in Hararghe, Ethiopia. Environ Pollut Climate Change 1: 118.

Sparks, A.H., Forbes, G.A., Hijmans, R.J. and Garrett, K.A., 2014. Climate change may have limited effect on global risk of potato late blight. Global change biology, 20(12), pp.3621-3631.

Tewodros Ayalew, 2014. Analysis of Seed Potato (Solanum tuberosum L.) Systems with Special Focus in Ethiopia: Review. Asian Journal of Agricultural Research,8:122-135.

Thiele, G., Theisen, K., Bonierbale, M. and Walker, T., 2010. Targeting the poor and hungry with potato science. Potato J, 37(3-4), pp.75-86.

Van Oort, P.A.J., Timmermans, B.G.H. and Van Swaaij, A.C.P.M., 2012. Why farmers' sowing dates hardly change when temperature rises. European Journal of Agronomy, 40, pp.102-111.

Wishart, J., George, T.S., Brown, L.K., Ramsay, G., Bradshaw, J.E., White, P.J. and Gregory, P.J., 2013. Measuring variation in potato roots in both field and glasshouse: the search for useful yield predictors and a simple screen for root traits. Plant and Soil, 368(1-2),231-249.

Yibrah G. and Araya A.( 2015).Impact of Climate Change on Potato Yield (Solanum tuberosum L.) At Mekelle Areas, in Northern Ethiopia, World Journal of Agricultural Sciences 11 (2): 62-69,

Yohannes, H. (2016). A Review on Relationship between Climate Change and Agriculture. Journal of Earth Science \& Climatic Change, $7: 335$..

Zarka, K.A., Greyling, R., Gazendam, I., Olefse, D., Felcher, K., Bothma, G., Brink, J., Quemada, H. and Douches, D.S., 2010. Insertion and characterization of the crylIa1 gene in the potato cultivar Spunta for resistance to potato tuber moth. Journal of the American Society for Horticultural Science, 135(4), 317-324.

Zebarth, B.J., Bélanger, G., Cambouris, N.A. and Ziadi, N., 2012. Sustainable potato production: Global case studies. Netherland.

Zhang, N., Si, H.J., Wen, G., Du, H.H., Liu, B.L. and Wang, D., 2011. Enhanced drought and salinity tolerance in transgenic potato plants with a BADH gene from spinach. Plant Biotechnology Reports, 5(1), pp.71-77. 